\title{
KELIMPAHAN KOLONI BAKTERI Vibrio sp. BERDASARKAN LOKASI BUDIDAYA TAMBAK UDANG DI KABUPATEN PIDIE
}

\section{THE ABUDANCE OF Vibrio sp. BACTERIAL COLONY BASED ON LOCATION OF SHRIMP PONDS CULTIVATION AT PIDIE DISTRICT}

\author{
Zahratul Idami $^{1)}$, Rizki Amelia Nasution ${ }^{2)}$ \\ ${ }^{1), 2)}$ Program Studi Biologi Universitas Islam Negeri Sumatera Utara Medan \\ zahratulidami@uinsu.ac.id
}

diterima : 16 Juli 2020; dipublikasi : 31 Oktober 2020

DOI: $10.32528 /$ bioma.v5i2.4012

\begin{abstract}
ABSTRAK
Penelitian ini bertujuan untuk mengisolasi dan menghitung kelimpahan koloni bakteri Vibrio sp. dari air tambak udang dengan 5 lokasi yang berbeda di Kecamatan Simpang Kabupaten Pidie, Aceh. Penelitian ini menggunakan metode eksploratif dan pengambilan sampel menggunakan purposive sampling. Isolasi bakteri menggunakan media selektif TCBSA. Perhitungan kelimpahan koloni Vibrio sp. menggunakan metode Total Plate Count. Hasil penelitian menunjukkan bahwa kelimpahan bakteri Vibrio sp. di Kecamatan Kembang Tanjong untuk kelima kategori lokasi tambak tergolong aman $\left(<10^{4} \mathrm{cfu} / \mathrm{ml}\right)$ yaitu $6,2 \times 10^{2}-2,6 \times 10^{3}$ $\mathrm{cfu} / \mathrm{ml}$. Berbeda halnya dengan tambak di Simpang Tiga yang masih dapat dikatakan aman hanya tambak K2T2 $\left(2,9 \times 10^{3} \mathrm{cfu} / \mathrm{ml}\right), \mathrm{K} 4 \mathrm{~T} 2\left(2,2 \times 10^{4} \mathrm{cfu} / \mathrm{ml}, \mathrm{K} 2 \mathrm{~T} 1\right.$; K5T; K5T2 $\left(2,3 \times 10^{4}\right.$ $\mathrm{cfu} / \mathrm{ml})$ karena kelimpahannya $<8,34$ x $10^{4} \mathrm{cfu} / \mathrm{ml}$, sedangkan bakteri Vibrio lainnya sudah bersifat patogen $\left(10^{5} \mathrm{cfu} / \mathrm{ml}\right)$. Hasil pengukuran kualitas air tambak menunjukkan rata-rata nilai salinitas 10,67-30,33 ppt, suhu 27,9-33, $8^{\circ} \mathrm{C}$, pH air 7,65-8,45, DO 5,35-8,42 dan kecerahan 20$55 \mathrm{~cm}$. Tidak adanya hubungan korelasi yang signifikan dari kualitas air tambak terhadap kelimpahan koloni bakteri Vibrio sp.
\end{abstract}

Kata kunci: Koloni, Bakteri, Vibrio, Tambak

\begin{abstract}
This research aimed to isolate and calculate the abundance of Vibrio sp. from shrimp pond water with had 5 different locations (ponds adjacent to agricultural areas (K1), settlements (K2), estuaries (K3), mangroves (K4), and far from the four categories (K5)) in Pidie District, Aceh. This research used an explorative method and the sampling used purposive sampling method. Isolation of bacteria used TCBSA as selective media. The abundance calculation of Vibrio sp. used Total Plate Count method. In addition, measured the quality of pond water too, consists of salinity, temperature, brightness, $\mathrm{pH}$, and DO (dissolved oxygen). The results showed that abundance of Vibrio sp. in Kembang Tanjong Subdistrict, the five categories of pond locations are classified as safe $\left(<10^{4} \mathrm{cfu} / \mathrm{ml}\right)$, wich range colony number $6.2 \times 10^{2}-2.6 \mathrm{x}$ $10^{3} \mathrm{cfu} / \mathrm{ml}$. Differently with ponds in Simpang Tiga which can still be said to be safe, only ponds K2T2 $\left(2.9 \times 10^{3} \mathrm{cfu} / \mathrm{ml}\right), \mathrm{K} 4 \mathrm{~T} 2\left(2.2 \times 10^{4} \mathrm{cfu} / \mathrm{ml}\right), \mathrm{K} 2 \mathrm{~T} 1 ; \mathrm{K} 5 \mathrm{~T} 1 ; \mathrm{K} 5 \mathrm{~T} 2\left(2.3 \times 10^{4} \mathrm{cfu} / \mathrm{ml}\right)$ because of their abundance $<8.34 \times 10^{4} \mathrm{cfu} / \mathrm{ml}$, but other ponds showed Vibrio bacteria were pathogenic $\left(10^{5} \mathrm{cfu} / \mathrm{ml}\right)$. The results of water quality measurements showed range of salinity 10.67-30.33 ppt, temperature 27.9-33.8 ${ }^{\circ} \mathrm{C}$, water $\mathrm{pH}$ 7.65-8.45, DO 5.35-8.42 and brightness $20-55 \mathrm{~cm}$. There was no significant corelation relationship between pond water quality and abundance of Vibrio $s p$.
\end{abstract}

Keywords: Colony, Bacteria, Vibrio, Pond

Zahratul Idami, et al. Kelimpahan Koloni. . . 


\section{PENDAHULUAN}

Budidaya perikanan tambak merupakan usaha yang dilakukan untuk memelihara, mengembangbiakkan, dan membesarkan biota budidaya perikanan dalam kolam dengan menciptakan kondisi perairan yang menyerupai habitat aslinya. Luas tambak yaitu $1 \mathrm{~m}^{2}-2$ Ha yang terbentuk secara alami maupun buatan manusia yang bersifat musiman atau permanen. Fungsi tambak untuk ekosistem perairan dan memperbanyak jenis biota air yang dibudidaya (Kordi, 2010).

Kabupaten Pidie memiliki pantai yang landai dan banyak sungai bermuara ke pantai sehingga lahannya cocok untuk pengembangan perikanan budidaya tambak. Terdapat dua kecamatan yang menjadi kawasan pertambakan di Kabupaten Pidie yaitu Kecamatan Simpang Tiga seluas 282 Ha dan Kembang Tanjong 842 Ha. Hasil produksi budidaya tambak pada Kecamatan Simpang Tiga sebanyak 242 ton dan Kembang Tanjong sebanyak 247 ton (Badan Pusat Statistika, 2014). Pada kedua kecamatan ini, komoditas utama didapatkan dari budidaya tambak udang. Udang yang dipelihara merupakan komoditas lokal yaitu udang windu (Penaeus monodon). Menurut data Badan Pusat Statistika (2014), hasil produksi budidaya tambak udang di kecamatan Simpang Tiga 1.788 juta dan Kembang Tanjong 2,225 juta.

Pada saat melakukan budidaya udang tidak terhindar dari serangan hama dan penyakit yang berasal dari lingkungan perairan tambak. Timbulnya penyakit berhubungan erat dengan kualitas air tambak. Kualitas air tambak antara satu lokasi dengan lokasi lainnya berbeda. Kualitas air tambak dipengaruhi oleh tata lokasi tambak dan pengaruh lingkungan disekitarnya seperti pertanian, pemukiman, manggrove dan muara. Hal ini menyebabkan tambak memiliki kualitas air yang berbeda. Bila kualitas air di dalam tambak tidak baik maka akan menyebabkan terjadinya penyakit pada biota budidaya (Kharisma \& Manan, 2012).

Salah satu penyakit yang sering menyerang budidaya udang disebabkan oleh mikroorganisme patogen seperti bakteri. Bakteri Vibrio sp. merupakan salah satu bakteri yang sangat familiar khususnya dalam lingkup budidaya perikanan, dimana bakteri ini merupakan salah satu penyebab penyakit yang dapat menimbulkan kematian massal pada budidaya udang (Felix et al., 2011). Vibrio sp. adalah bakteri yang menyebabkan penyakit vibriosis (Irianto, 2005). Gejala klinis udang apabila terserang 
vibriosis yaitu insang dan hepatopankreas berwarna merah kecoklatan, bagian telson, uropod dan abdominal berwarna merah, dan berenang lambat (Ramesh et al., 2014).

Beberapa spesies Vibrio yang pernah dilaporkan sebagai penyebab infeksi penyakit vibriosis diantaranya $V$. parahaemolyticus, V. vulnificus, V. anguillarum, V. alginolyticus, V. splendidus dan V. harveyi (Lightner, 1996; Chatterjee \& Haldar, 2012). Anggota Crustacea yang pernah dilaporkan terserang vibriosis yaitu Penaeus monodon (Tran et al. 2013), Panulirus Humarus (Raissy et al. 2011), Litopenaeus vannamei (Kharisma \& Manan, 2012; Apriliani et al., 2016), dan Macrobrachium rosenbergii (de Man) (Bintari et al, 2016).

Bakteri Vibrio sp. merupakan jenis patogen yang menginfeksi dan menyebabkan penyakit pada kondisi udang yang lemah dan lingkungan yang ekstrim. Perubahan sifatsifat kimia air yang mendadak seperti suhu dan salinitas maupun kepadatan larva yang tinggi akan mempercepat berkembangnya bakteri tersebut (Mancuso et al., 2015). Vibrio akan bersifat patogen apabila kelimpahannya dalam air pemeliharaan telah mencapai 8,35 x $10^{4} \mathrm{cfu} / \mathrm{ml}$ atau lebih. Oleh karena itu, dalam upaya penanggulangannya tidak perlu dibasmi habis, hanya perlu dikendalikan sampai batas yang aman yaitu $<10^{4} \mathrm{cfu} / \mathrm{ml}$ (Zafran dan Roza, 1998). Kepadatan bakteri dalam air melebihi $10^{6} \mathrm{cfu} / \mathrm{ml}$ dapat menimbulkan 90\% kematian (Tran et al., 2013) pada benur stadium larva dan post larva dan udang dewasa (Sureshvarr et al., 2011).

Penelitian ini bertujuan untuk mengisolasi bakteri Vibrio $s p$. dari air tambak pada lima lokasi tambak yang berbeda di Kabupaten Pidie, dan menghitung kelimpahan koloni bakteri Vibrio. Diharapkan penelitian ini dapat memberikan informasi tentang kelimpahan Vibrio sp. sebagai deteksi dini vibriosis dan meminimalisir udang budidaya terserang penyakit.

\section{METODE}

Penelitian ini menggunakan peralatan seperti botol sampel, $\mathrm{pH}$ meter, refraktometer, DO meter, Seicchi disc, termometer, GPS (Global Position System), Ice box, pipet volume, cawan petri, tabung reaksi, erlemeyer, jarum ose, oven, autoclaf, inkubator, bunsen, hot plate, colony counter, timbangan analitik, kaca preparat dan mikroskop. Bahan yang digunakan adalah sampel air tambak, serbuk TCBSA 
(Thiosulfate Citrate Bilesalt Sucrose Agar), aquadest, $\mathrm{KCl}, \mathrm{MgSO} 4, \mathrm{NaCl}$, minyak immersi, alkohol 70\%, alkohol 95\%, lugol, kristal violet, safranin dan es batu.

Metode yang digunakan pada penelitian ini adalah metode survei eksploratif dan pengambilan sampel menggunakan metode purposive sampling. Lokasi pengambilan sampel penelitian ini di Kabupaten Pidie yang mencakup Kecamatan Simpang Tiga dan Kembang Tanjong, Provinsi Aceh (Tabel 1). Tambak yang dipilih yaitu tambak budidaya udang windu (Penaeus monodon) yang dikelola secara ekstensif dengan sistem pengelolaannya bergantung pada lingkungan (Kordi, 2010) dengan luas $\pm 1 \mathrm{Ha}$, dan padat tebar benur udang 4-8 ekor $/ \mathrm{m}^{2}$. Kondisi tambak saat penelitian yaitu benur udang sudah ditebar dengan PL 20 dan usia tebar 16 hari. udang PL 20 setelah ditebar. Tambak ekstensif (tradisional) tidak menggunakan aerasi, sistem pemasukan air dengan menggunakan satu pintu menuju saluran air, dan tidak menggunakan pakan buatan.

Lokasi tambak yang menjadi penelitian terdiri atas 5 kategori lokasi. Kelima lokasi tersebut adalah K1 (tambak yang dekat kawasan pertanian dengan jarak <500 m), K2 (tambak yang dekat pemukiman dengan jarak <500 m), K3 (tambak dekat dengan muara dengan jarak <500 m), K4 (tambak dekat dengan kawasan manggrove dengan jarak <500 m), dan K5 (tambak yang jauh dari lokasi pemukiman, pertanian, muara dan manggrove dengan jarak $>500 \mathrm{~m})($ Gambar 1).

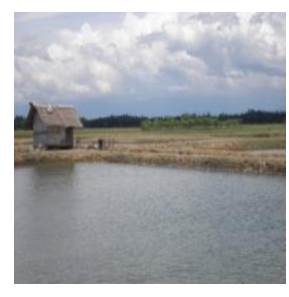

$\mathrm{K} 1$

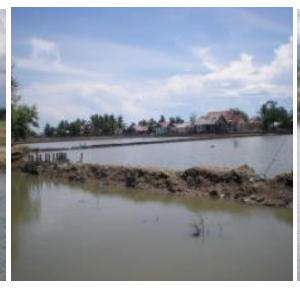

K2

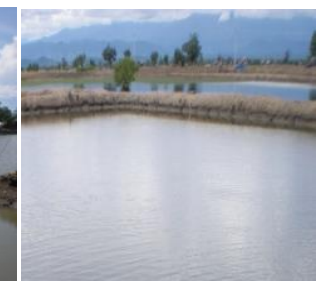

K3

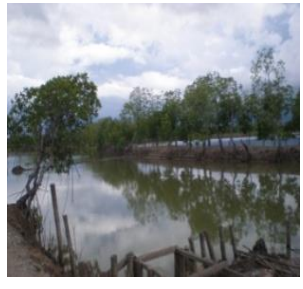

K4

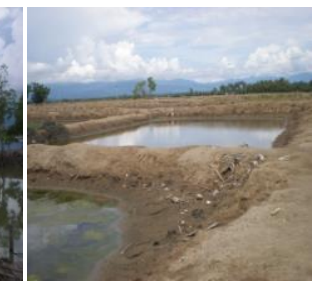

K5

Gambar 1. Kategori lokasi budidaya perikanan tambak

Berikut ini letak geografis dari lokasi pengambilan sampel air tambak di Kabupaten Pidie dengan menggunakan Global Position System (GPS) (Tabel 1). 
Tabel 1. Letak geografis lokasi tambak penelitian

\begin{tabular}{|c|c|c|c|c|c|c|c|c|c|}
\hline \multirow{2}{*}{\multicolumn{2}{|c|}{$\begin{array}{c}\text { Lokasi } \\
\text { Tambak }\end{array}$}} & \multicolumn{2}{|c|}{ Letak Geografis } & \multirow{2}{*}{$\begin{array}{c}\text { Nama } \\
\text { Desa }\end{array}$} & \multirow{2}{*}{\multicolumn{2}{|c|}{$\begin{array}{c}\text { Lokasi } \\
\text { Tambak }\end{array}$}} & \multicolumn{2}{|c|}{ Letak Geografis } & \multirow{2}{*}{$\begin{array}{c}\text { Nama } \\
\text { Desa }\end{array}$} \\
\hline & & $\begin{array}{c}\text { Lintang } \\
\text { Utara }\end{array}$ & $\begin{array}{l}\text { Bujur } \\
\text { Timur }\end{array}$ & & & & $\begin{array}{c}\text { Lintang } \\
\text { Utara }\end{array}$ & $\begin{array}{l}\text { Bujur } \\
\text { Timur }\end{array}$ & \\
\hline \multicolumn{5}{|c|}{ Kecamatan Simpang Tiga } & \multicolumn{5}{|c|}{ Kecamatan Kembang Tanjong } \\
\hline \multirow{2}{*}{ K1 } & $\mathrm{T} 1$ & ${\mathrm{~N} 05^{0} 21.541^{1}}^{1}$ & E $095^{0} 58.983^{1}$ & \multirow{2}{*}{$\begin{array}{l}\text { Paleue } \\
\text { Raya }\end{array}$} & \multirow{2}{*}{ K1 } & $\mathrm{T} 1$ & $\mathrm{~N} 05^{0} 18.892^{1}$ & E $096^{0} 02.102^{1}$ & \multirow{2}{*}{ Meraksa } \\
\hline & $\mathrm{T} 2$ & $\mathrm{~N} 05^{0} 21.495^{1}$ & E $095^{0} 58.964^{1}$ & & & $\mathrm{~T} 2$ & $\mathrm{~N} 05^{0} 18.823^{1}$ & E $096^{0} 02.052^{1}$ & \\
\hline \multirow{2}{*}{ K2 } & $\mathrm{T} 1$ & $\mathrm{~N} 05^{0} 22.209^{1}$ & E $095^{0} 58.339^{1}$ & \multirow{2}{*}{$\begin{array}{c}\text { Peukan } \\
\text { Sot }\end{array}$} & \multirow{2}{*}{ K2 } & $\mathrm{T} 1$ & $\mathrm{~N} 05^{0} 17.846^{1}$ & E $096^{0} 04.034^{1}$ & \multirow{2}{*}{ Jemrang } \\
\hline & $\mathrm{T} 2$ & $\mathrm{~N} 05^{0} 22.346^{1}$ & E $095^{0} 58.346^{1}$ & & & $\mathrm{~T} 2$ & $\mathrm{~N} 05^{0} 17.816^{1}$ & E $096^{0} 04.128^{1}$ & \\
\hline \multirow{2}{*}{ K3 } & $\mathrm{T} 1$ & $\mathrm{~N} 05^{0} 21.609^{1}$ & E $095^{0} 59.664^{1}$ & \multirow{2}{*}{$\begin{array}{l}\text { Menasah } \\
\text { Lhee }\end{array}$} & \multirow{2}{*}{ K3 } & $\mathrm{T} 1$ & $\mathrm{~N} 05^{0} 19.642^{1}$ & E $096^{0} 02.540^{1}$ & \multirow{2}{*}{$\begin{array}{c}\text { Pasi Ie } \\
\text { Leubeu }\end{array}$} \\
\hline & $\mathrm{T} 2$ & $\mathrm{~N} 05^{0} 21.702^{1}$ & E $095^{0} 59.671^{1}$ & & & $\mathrm{~T} 2$ & $\mathrm{~N} 05^{0} 19.558^{1}$ & E $096^{0} 02.506^{1}$ & \\
\hline \multirow{2}{*}{ K4 } & $\mathrm{T} 1$ & $\mathrm{~N} 05^{0} 21.881^{1}$ & E $095^{0} 58.456^{1}$ & \multirow{2}{*}{ Ceubrek } & \multirow{2}{*}{ K4 } & $\mathrm{T} 1$ & $\mathrm{~N} 05^{0} 17.986^{1}$ & E $096^{0} 03.631^{1}$ & \multirow{2}{*}{$\begin{array}{l}\text { Pasi } \\
\text { Lhok }\end{array}$} \\
\hline & $\mathrm{T} 2$ & $\mathrm{~N} 05^{0} 21.864^{1}$ & E $095^{0} 58.495^{1}$ & & & $\mathrm{~T} 2$ & ${\mathrm{~N} 05^{0} 18.019^{1}}^{1}$ & E $096^{0} 03.572^{1}$ & \\
\hline \multirow{2}{*}{ K5 } & $\mathrm{T} 1$ & $\mathrm{~N} 05^{0} 21.429^{1}$ & E $095^{0} 59.453^{1}$ & \multirow{2}{*}{ Kupula } & \multirow{2}{*}{ K5 } & $\mathrm{T} 1$ & $\mathrm{~N} 05^{0} 18.910^{1}$ & E $096^{0} 02.936^{1}$ & \multirow{2}{*}{ Lancang } \\
\hline & $\mathrm{T} 2$ & $\mathrm{~N} 05^{0} 21.478^{1}$ & E $095^{0} 59.454^{1}$ & & & $\mathrm{~T} 2$ & $\mathrm{~N} 05^{0} 18.833^{1}$ & E $096^{0} 02.861^{1}$ & \\
\hline
\end{tabular}

\section{Keterangan :}

K1: Kategori tambak yang berdekatan dengan kawasan pertanian $(<500 \mathrm{~m})$

K2: Kategori tambak yang berdekatan dengan kawasan pemukiman $(<500 \mathrm{~m})$

K3: Kategori tambak yang berdekatan dengan muara $(<500 \mathrm{~m})$

K4: Kategori tambak yang berdekatan dengan kawasan manggrove $(<500 \mathrm{~m})$

K5: Kategori tambak yang tidak termasuk ke empat kategori tersebut $>500 \mathrm{~m}$

T1: Tambak 1 dan T2 : Tambak 2

\section{Isolasi Bakteri Vibrio sp.}

Bakteri Vibrio sp. diisolasi dari air tambak sebanyak 20 sampel dari 10 lokasi tambak yang berbeda berdasarkan Tabel 1. Sampel air diambil dari 5 lokasi tambak udang yang berbeda. Pengambilan sampel air tambak dilakukan dengan memegang bagian bawah botol sampel yang telah disterilkan menggunakan autoclaf. Botol sampel dicelupkan ke dalam air tambak dengan posisi leher botol miring ke bawah. Botol tersebut dicelupkan hingga mencapai kedalaman $\pm 20 \mathrm{~cm}$. Botol yang dicelupkan ditutup di dalam air untuk menghindari kontaminasi bakteri dari udara. Selanjutnya dimasukkan ke dalam ice box untuk dianalisis di Laboratorium Mikrobiologi, Jurusan Biologi FMIPA Universitas Syiah Kuala, Banda Aceh

Sampel air tambak sebanyak $1 \mathrm{ml}$ dimasukkan ke dalam tabung reaksi steril yang berisi $9 \mathrm{ml}$ larutan trisalt yang telah disterilkan. Larutan diaduk sampai homogen dan diberi tanda $10^{-1}$. Diambil $1 \mathrm{ml}$ sampel dari sampel tabung pertama dan dimasukkan ke dalam $9 \mathrm{ml}$ trisalt yang lain. Proses ini dilakukan sampai didapatkan pengenceran $10^{-4}$. Diambil $1 \mathrm{ml}$ dari masing-masing pengenceran, dimasukkan ke cawan petri dan dibuat duplo. Selanjutnya ditambahkan media TCBSA (Thiosulfate Citrate BileSalt Sucrose Agar). Diaduk dengan membentuk angka 8. Setelah media mengeras, 
diinkubasi dalam inkubator pada suhu $34{ }^{0} \mathrm{C}$ selama 48 jam dengan posisi terbalik (Chau et al., 2011).

\section{Perhitungan Koloni Bakteri (cfu/ml)}

Metode yang digunakan untuk menghitung jumlah koloni Vibrio adalah metode hitungan cawan petri atau disebut Total Plate Count. Metode ini menghitung jumlah koloni Vibrio sp. yang tumbuh pada media biakan yang diisolasi dari air tambak. Pertumbuhan koloni dicatat dari setiap cawan petri. Dihitung Total Plate Count (TPC) koloni bakteri yang terdapat pada setiap tingkat pengenceran menggunakan colony counter (Radji, 2011).

Jumlah koloni bakteri Vibrio sp. yang tumbuh dikalkulasi dengan rumus berikut ini untuk menghitung kelimpahan bakteru (CFU/ml) (Cappucino \& Sherman, 2011):

$\mathbf{C F U} / \mathbf{m l}=$ Koloni Bakteri $\mathbf{x}$ Jumlah yang Diambil $\mathbf{x}$ Tingkat Pengenceran yang Tumbuh $\quad(\mathrm{ml})$

\section{Pewarnaan Gram}

Sediaan bakteri Vibrio $s p$. yang telah diisolasi dibuat dengan teknik aseptis. Sediaan bakteri diaduk dengan aquadest, kemudian difiksasi diatas api. Bakteri yang telah difiksasi ditetesi pewarna kristal violet dan dibiarkan selama 1 menit. Setelah itu dicuci dengan air mengalir. Ditetesi dengan alkohol 95\% dan dibiarkan selama 10-20 detik. Perlu diingat bahwa penetesan alkohol 95\% jangan telalu berlebihan. Ditetesi safranin dan dibiarkan selama 20-30 detik, kemudian dicuci dengan air mengalir. Dikeringkan dengan kertas serap, ditambahkan minyak emersi dan diamati dibawah mikroskop (Lay, 1994).

\section{Pengukuran Kualitas Air Tambak}

Parameter kualitas air tambak yang diteliti terdiri dari suhu (termometer), kecerahan (Seichi disc), salinitas (refraktometer), oksigen terlarut (DO meter) dan derajat keasaman ( $\mathrm{pH}$ meter) yang diukur secara in situ dengan 3 kali ulangan. Pengukuran ini dilakukan untuk menganalisa air tambak yang diteliti sesuai dengan batas untuk pertumbuhan udang windu berdasarkan Tim Perikanan WWF-Indonesia. (2014). Selain itu, dilakukan pula analisis korelasi menggunakan SPSS 17 untuk melihat hubungan antara kualitas air tambak dengan jumlah koloni bakteri.

\section{HASIL DAN PEMBAHASAN}


Vibrio merupakan salah satu bakteri patogen yang tergolong dalam divisi Bakteria, klas Shizomicetes, ordo Eubacteriales, famili Vibrionaceae dan genus Vibrio (Austin, 1988). Menurut Bergey's Manual of Systematic Bacteriology (Holt et al., 1994), anggota bakteri Genus Vibrio mempunyai ciri-ciri antara lain berbentuk batang pendek, bersifat gram negatif, memiliki flagel, tidak berspora, tidak memiliki kapsul, bersifat fakultatif aerob dan berkembang biak dengan pembelahan biner, tumbuh pada media selektif Thiosulfate Citrate Bile Salt Sucrose Agar (TCBSA) dengan koloni berwarna kekuningan, orange dan hijau.

Hasil isolasi bakteri dari penelitian ini ditemukan dua jenis koloni bakteri Vibrio $s p$. yaitu koloni bakteri yang berwarna hijau-biru dan koloni putih-kekuningan (Gambar 2). Warna koloni yang berwarna hijau menunjukkan sifat Vibrio yang tidak dapat memfermentasi sukrosa sedangkan koloni berwarna kuning dapat memfermentasi sukrosa dan menurunkan pH dalam media TCBSA (Ihsan \& Retnaningrum, 2017). Selanjutnya Rahmanto et al., (2014) telah mengidentifikasi jenis Vibrio dari warna koloni yang terbentuk. Koloni Vibrio berwarna hijau yang tumbuh pada media TCBSA memiliki kemiripan $86 \%$ dengan $V$. fischery dan $V$. mimicus, sedangkan koloni berwarna kuning memiliki kemiripan 90-95 \% dengan $V$. alginolyticus dan $V$. harveyii.
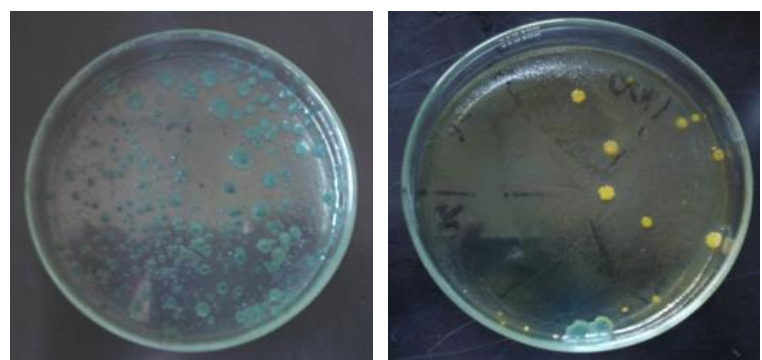

Gambar 2. Koloni Bakteri Vibrio sp.

Pengamatan morfologi dari bakteri Vibrio sp. dilakukan dengan pewarnaan gram. Dibawah mikroskop terlihat koloni Vibrio yang tumbuh menyebar di permukaan kaca objek berbentuk batang bengkok (koma) dan berkoloni. Warna yang terlihat dibawah mikroskop yaitu berwarna merah. Ini artinya Vibrio merupakan salah satu bakteri gram negatif. Campbell et al. (2011) menjelaskan kelompok bakteri gram negatif memiliki jumlah peptidoglikan sedikit dengan struktur dinding sel yang kompleks. 
Data perhitungan kelimpahan koloni bakteri Vibrio sp. dari air tambak di Kecamatan Simpang Tiga dan Kembang Tanjong dapat dilihat pada Tabel 2. Koloni Vibrio ditemukan tersebar di semua lokasi tambak. Ini berarti Vibrio toleran terhadap kondisi perairan tambak dengan kualitas air yang bervariasi (Tabel 3). Kelimpahan koloni Vibrio sp pada lahan tambak di Kecamatan Simpang Tiga yang berada dibawah nilai $<8,35 \times 10^{4} \mathrm{cfu} / \mathrm{ml}$ hanya tambak K2T1, K2T2, K4T2, K5T1 dan K5T2. Sedangkan kategori tambak lainnya sudah dikatakan tergolong berbahaya $\left(\geq 8,35 \times 10^{4}\right.$ $\mathrm{cfu} / \mathrm{ml}$ ) karena Vibrio telah bersifat patogen. Patogenitas bakteri sangat dipengaruhi oleh jumlah populasi bakteri tersebut, semakin tinggi kepadatannya maka semakin banyak patogen (Zafran dan Roza, 1998). Hal ini berbeda dengan kelimpahan koloni bakteri Vibrio pada air tambak di Kecamatan Kembang Tanjong yang keseluruhan memiliki jumlah koloni $<10^{4} \mathrm{cfu} / \mathrm{ml}$.

Tabel 2. Data Jumlah koloni Vibrio

\begin{tabular}{|c|c|c|c|c|c|c|c|}
\hline \multicolumn{2}{|c|}{$\begin{array}{c}\text { Lokasi } \\
\text { Tambak }\end{array}$} & $\begin{array}{l}\text { Jumlah koloni } \\
\quad(\mathrm{cfu} / \mathrm{ml})\end{array}$ & $\begin{array}{c}\text { Rata-rata } \\
\pm \text { Standar } \\
\text { deviasi }\end{array}$ & \multicolumn{2}{|c|}{$\begin{array}{c}\text { Lokasi } \\
\text { Tambak }\end{array}$} & $\begin{array}{l}\text { Jumlah koloni } \\
\quad(\mathrm{cfu} / \mathrm{ml})\end{array}$ & $\begin{array}{c}\text { Rata-rata } \\
\pm \text { Standar } \\
\text { deviasi }\end{array}$ \\
\hline \multicolumn{4}{|c|}{ Kecamatan Simpang Tiga } & \multicolumn{4}{|c|}{ Kecamatan Kembang Tanjong } \\
\hline \multirow{2}{*}{ K1 } & $\mathrm{T} 1$ & $2,2 \times 10^{5}$ & \multirow{2}{*}{$\begin{array}{c}2,0 \times 10^{5} \\
\pm 0,28\end{array}$} & \multirow{2}{*}{$\mathrm{K} 1$} & $\mathrm{~T} 1$ & $2,6 \times 10^{3}$ & \multirow{2}{*}{$\begin{array}{c}2,1 \times 10^{3} \\
\pm 0,71\end{array}$} \\
\hline & $\mathrm{T} 2$ & $1,8 \times 10^{5}$ & & & $\mathrm{~T} 2$ & $1,6 \times 10^{3}$ & \\
\hline \multirow{2}{*}{$\mathrm{K} 2$} & $\mathrm{~T} 1$ & $2,3 \times 10^{4}$ & \multirow{2}{*}{$\begin{array}{c}1,3 \times 10^{4} \\
\pm 1,42\end{array}$} & \multirow{2}{*}{$\mathrm{K} 2$} & $\mathrm{~T} 1$ & $1,1 \times 10^{3}$ & \multirow{2}{*}{$\begin{array}{c}1,1 \times 10^{3} \\
\pm 0,00\end{array}$} \\
\hline & $\mathrm{T} 2$ & $2,9 \times 10^{3}$ & & & $\mathrm{~T} 2$ & $1,1 \times 10^{3}$ & \\
\hline \multirow{2}{*}{$\mathrm{K} 3$} & $\mathrm{~T} 1$ & $2,2 \times 10^{5}$ & \multirow{2}{*}{$\begin{array}{c}2,3 \times 10^{5} \\
\pm 0,07\end{array}$} & \multirow{2}{*}{$\mathrm{K} 3$} & $\mathrm{~T} 1$ & $2,0 \times 10^{3}$ & \multirow{2}{*}{$\begin{array}{c}2,2 \times 10^{3} \\
\pm 0,21\end{array}$} \\
\hline & $\mathrm{T} 2$ & $2,3 \times 10^{5}$ & & & $\mathrm{~T} 2$ & $2,3 \times 10^{3}$ & \\
\hline \multirow{2}{*}{ K4 } & $\mathrm{T} 1$ & $1,7 \times 10^{5}$ & \multirow{2}{*}{$\begin{array}{c}9,6 \times 10^{4} \\
\pm 1,05\end{array}$} & \multirow{2}{*}{ K4 } & $\mathrm{T} 1$ & $6,2 \times 10^{2}$ & \multirow{2}{*}{$\begin{array}{c}7,0 \times 10^{2} \\
\pm 1,13\end{array}$} \\
\hline & $\mathrm{T} 2$ & $2,2 \times 10^{4}$ & & & $\mathrm{~T} 2$ & $7,8 \times 10^{2}$ & \\
\hline \multirow{2}{*}{ K5 } & $\mathrm{T} 1$ & $2,3 \times 10^{4}$ & \multirow{2}{*}{$\begin{array}{c}2,3 \times 10^{4} \\
\pm 0,00\end{array}$} & \multirow{2}{*}{ K5 } & $\mathrm{T} 1$ & $1,3 \times 10^{3}$ & \multirow{2}{*}{$\begin{array}{c}1,4 \times 10^{3} \\
\pm 0,07\end{array}$} \\
\hline & $\mathrm{T} 2$ & $2,3 \times 10^{4}$ & & & $\mathrm{~T} 2$ & $1,4 \times 10^{3}$ & \\
\hline
\end{tabular}

\section{Jumlah Koloni Vibrio sp. pada Tiap-Tiap Lokasi Budidaya Tambak Udang}

Kl (Kategori tambak yang berdekatan dengan kawasan pertanian)

Kategori tambak yang berdekatan dengan kawasan pertanian, memiliki salinitas yang rendah bila dibandingkan dengan kategori tambak yang lain yaitu tambak di Simpang Tiga berkisar 10,7-11,7 ppt, dan tambak Kembang Tanjong 15-17 ppt. Hal ini 
karena banyaknya pemasukan air tawar dibandingkan air laut dalam tambak. Selain itu, kualitas air tambak diduga akan terganggu oleh pestisida yang berasal dari buangan pertanian. Pestisida dapat mengakibatkan kondisi air tambak memburuk. Irianto (2005) mengatakan kondisi air yang buruk akan memacu stress ikan dan akibatnya jumlah koloni Vibrio pun tinggi. Jumlah koloni Vibrio tertinggi kedua terdapat pada kategori ini yaitu sebanyak $2,0 \times 10^{5} \mathrm{cfu} / \mathrm{ml}$ pada tambak di Simpang Tiga dan $2,1 \times 10^{3} \mathrm{cfu} / \mathrm{ml}$ pada tambak di Kembang Tanjong.

K2 (Kategori tambak yang berdekatan dengan pemukiman)

Tambak yang berdekatan dengan pemukiman memiliki pengaruh terhadap pertumbuhan Vibrio. Hal ini dikarenakan polutan yang berasal dari pemukiman masuk ke badan air yang nantinya akan masuk ke dalam saluran pemasukan air tambak. Air limbah pemukiman akan mengurangi kualitas air tergantung pada besaran polutan dan intesitasnya (Kordi, 2010). Polutan terbesar terdapat pada tambak di Simpang Tiga sehingga jumlah koloni Vibrio pun tinggi $\left(1,3 \times 10^{4} \mathrm{cfu} / \mathrm{ml}\right)$ dibandingkan tambak di Kembang Tanjong $\left(1,1 \times 10^{3} \mathrm{cfu} / \mathrm{ml}\right)$.

K3 (Kategori tambak yang berdekatan dengan muara)

Tambak yang terletak dekat dengan muara memiliki potensi yang besar terhadap populasi Vibrio yang tinggi. Hal ini sesuai dengan pernyataan Felix et al. (2011) yang menyatakan bahwa habitat Vibrio adalah air laut. Selain itu, muara juga merupakan saluran air sebagai sumber pemasukan air untuk tambak, serta saluran terakhir dari pembuangan limbah (limbah tambak, pertanian dan pemukiman) sehingga populasi Vibrio pun tinggi. Jumlah koloni Vibrio terbanyak terdapat pada tambak di kategori ini bila dibandingkan dengan tambak yang lain. Jumlah koloni Vibrio pada kategori ini adalah 2,3 x $10^{5} \mathrm{cfu} / \mathrm{ml}$ (Simpang Tiga) dan 2,2 x $10^{3} \mathrm{cfu} / \mathrm{ml}$ (Kembang Tanjong).

K4 (Kategori tambak yang berdekatan dengan kawasan mangrove)

Tambak yang berdekatan dengan kawasan mangrove memiliki pengaruh yang besar terhadap jumlah koloni Vibrio. Menurut penelitian Tyas et al. (2018) ditemukan jumlah isolasi bakteri pada kawasan manggrove lebih sedikit dibandingkan pada area tidak bermanggrove. Hal ini sesuai untuk kelimpahan Vibrio di Kembang Tanjong (7,0 x $\left.10^{2} \mathrm{cfu} / \mathrm{ml}\right)$. Akan tetapi, berbeda halnya dengan tambak di Simpang Tiga $\left(9,6 \times 10^{4}\right.$ $\mathrm{cfu} / \mathrm{ml})$. 
K5 (Kategori tambak yang tidak termasuk ke empat kategori tersebut)

Tambak pada kategori ini merupakan tambak yang dipilih berjauhan dari muara, pemukiman, pertanian dan manggrove. Hal ini dimaksudkan untuk melihat kelimpahan koloni Vibrio sp. yang tidak dipengaruhi oleh faktor-faktor dari keempat kategori yang lain. Pada tambak di Kembang Tanjong terlihat jumlah koloni Vibrio sp. 1,4 x $10^{3}$ cfu/ml dan Simpang Tiga, 2,3 x $10^{4} \mathrm{cfu} / \mathrm{ml}$. Jumlah koloni Vibrio sp. ini masih dalam kategori aman yaitu $<8,35 \times 10^{4} \mathrm{cfu} / \mathrm{ml}$. Hal ini diduga karena tidak adanya zat pencemar yang masuk kedalam tambak.

\section{Kualitas Air}

Kualitas air tambak yang diukur pada penelitian ini terdiri dari parameter fisika (suhu dan kecerahan), dan parameter kimia ( $\mathrm{pH}$, salinitas dan kadar oksigen terlarut). Kualitas air tambak sangat berpengaruh terhadap pertumbuhan udang. Pengukuran kualitas air ini juga berfungsi untuk melihat kelayakan dari air tambak untuk budidaya udang. Menurut Tim Perikanan WWF-Indonesia (2014) kisaran kualitas air tambak untuk udang windu (Penaeus monodon) selama pemeliharaan yaitu suhu berkisar antara 29-32 ${ }^{\circ} \mathrm{C}$, salinitas 5-40 ppt, pH 7,6 - 8,8, oksigen terlarut (Disolve Oxygen) > 3, dan kecerahan 30-40 cm. Hasil pengukuran dari 20 air tambak diperoleh nilai suhu berkisar antara $27,9-33.8^{\circ} \mathrm{C}$, salinitas antara 10,67 - 30,33 ppt, pH air tambak antara 7,65 8,45 , oksigen terlarut 5,35 - 8,42 dan kecerahan antara 20 - $55 \mathrm{~cm}$ (Tabel 3). Kualitas air tambak berupa suhu, salinitas, $\mathrm{pH}$, dan oksigen terlarut dari air tambak di Simpang Tiga dan Kembang Tanjong masih dalam kisaran yang layak untuk budidaya udang, kecuali kecerahan. Hanya ait tambak K4T2, K5T1, K5T2 (Simpang Tiga) dan K3T1 (Kembang Tanjong) yang memenuhi nilai kecerahan yang berkisar antara 30-40 cm. Jika kecerahan > $45 \mathrm{~cm}$ artinya kepadatan plankton berkurang, sebaliknya jika kecerahan < $30 \mathrm{~cm}$ artinya jumlah plankton dalam air tambak padat (Tim Perikanan WWF Indonesia, 2014)

Tabel 3. Data pengukuran parameter kualitas air

\begin{tabular}{ccccccc}
\hline \multirow{2}{*}{$\begin{array}{c}\text { Lokasi } \\
\text { Tambak }\end{array}$} & \multicolumn{6}{c}{ Parameter Kualitas Air } \\
\cline { 2 - 6 } & Salinitas $(\mathbf{p p t})$ & $\mathbf{p H}$ & DO $(\mathbf{m g} / \mathbf{l})$ & Suhu $\left({ }^{\mathbf{0}} \mathbf{C}\right)$ & Kecerahan $(\mathbf{c m})$ \\
\hline $\mathrm{K}-1$ & $\mathrm{~T} 1$ & 16 & 7,58 & 5,42 & 33,7 & 20
\end{tabular}




\begin{tabular}{|c|c|c|c|c|c|c|}
\hline \multirow{2}{*}{\multicolumn{2}{|c|}{$\begin{array}{c}\text { Lokasi } \\
\text { Tambak }\end{array}$}} & \multicolumn{5}{|c|}{ Parameter Kualitas Air } \\
\hline & & Salinitas (ppt) & pH & DO (mg/l) & Suhu $\left({ }^{\circ} \mathrm{C}\right)$ & Kecerahan (cm) \\
\hline \multirow{3}{*}{ K-2 } & $\mathrm{T} 2$ & 15,33 & 7,58 & 5,44 & 33,8 & 23,33 \\
\hline & $\mathrm{T} 1$ & 25 & 7,58 & 6,08 & 33,3 & 20 \\
\hline & $\mathrm{T} 2$ & 24,67 & 7,59 & 6,13 & 33,2 & 28,33 \\
\hline \multirow{2}{*}{$\mathrm{K} 3$} & $\mathrm{~T} 1$ & 23,33 & 8,25 & 6,53 & 29,9 & 30 \\
\hline & $\mathrm{T} 2$ & 24,63 & 8,42 & 6,55 & 29,3 & 26,67 \\
\hline \multirow{2}{*}{ K4 } & $\mathrm{T} 1$ & 20.33 & 7.78 & 6.18 & 33.7 & 26.67 \\
\hline & $\mathrm{T} 2$ & 20.33 & 7.89 & 6.22 & 33.7 & 36.67 \\
\hline \multirow{2}{*}{ K5 } & $\mathrm{T} 1$ & 18.67 & 8.22 & 5.06 & 31.1 & 30 \\
\hline & $\mathrm{T} 2$ & 18.33 & 8.23 & 5.06 & 31.1 & 40 \\
\hline \multicolumn{7}{|c|}{ Kecamatan Kembang Tanjong } \\
\hline \multirow{2}{*}{$\mathrm{K} 1$} & $\mathrm{~T} 1$ & 10.67 & 7,65 & 5.35 & 32.5 & 20 \\
\hline & $\mathrm{T} 2$ & 11.67 & 7.77 & 5.36 & 33.8 & 20 \\
\hline \multirow{2}{*}{$\mathrm{K} 2$} & $\mathrm{~T} 1$ & 21.33 & 8,23 & 6.24 & 27.9 & 26.67 \\
\hline & $\mathrm{T} 2$ & 21 & 8.23 & 6.14 & 28.6 & 25 \\
\hline \multirow{2}{*}{$\mathrm{K} 3$} & $\mathrm{~T} 1$ & 19.33 & 8.25 & 5.54 & 30.6 & 40 \\
\hline & $\mathrm{T} 2$ & 20 & 8.23 & 5.56 & 31.3 & 45 \\
\hline \multirow{2}{*}{$\mathrm{K} 4$} & $\mathrm{~T} 1$ & 30,33 & 8,16 & 8,31 & 28.6 & 50.33 \\
\hline & $\mathrm{T} 2$ & 29.67 & 8.24 & 8.42 & 29.9 & 43.33 \\
\hline \multirow{2}{*}{ K5 } & $\mathrm{T} 1$ & 24.33 & 8.08 & 5.42 & 30.1 & 55 \\
\hline & $\mathrm{T} 2$ & 23.33 & 8.45 & 5.56 & 30.7 & 50 \\
\hline
\end{tabular}

Hubungan antara kelimpahan koloni Vibrio sp. dengan hasil pengukuran kualitas air tambak dianalisis menggunakan SPSS untuk mengamati korelasinya. Nilai korelasi jumlah koloni dengan suhu air tambak 0,197, salinitas air tambak yaitu 0,098, pH air tambak 0,152, kelarutan air tambak 0,016, dan kecerahan 0,405. Nilai korelasi itu menunjukkan kualitas air tidak terlalu berpengaruh terhadap jumlah koloni bakteri Vibrio sp. karena nilai kolerasi < 0,5. Hal ini menunjukkan adanya faktor lain diluar kualitas air tambak yang mempengaruhi kelimpahan bakteri Vibrio sp.

\section{KESIMPULAN DAN SARAN}

Kelimpahan koloni bakteri Vibrio sp. pada lokasi budidaya perikanan tambak memiliki variasi. Lokasi budidaya perikanan tambak di Kecamatan Simpang Tiga sebagian besar melebihi batas < 8,34 x $10^{4} \mathrm{cfu} / \mathrm{ml}$. Berbeda halnya dengan kategori tambak Kecamatan Kembang Tanjong yang sesuai dengan batas toleransi $<10^{4} \mathrm{cfu} / \mathrm{ml}$. Jumlah koloni bakteri Vibrio tertinggi terdapat pada kategori tambak K3 (kategori Zahratul Idami, et al. Kelimpahan Koloni. . . 
tambak yang berdekatan dengan muara) pada masing-masing kecamatan, yaitu dengan jumlah koloninya $2,3 \times 10^{5} \mathrm{cfu} / \mathrm{ml}$ (Simpang Tiga) dan $2,2 \times 10^{3} \mathrm{cfu} / \mathrm{ml}$ (Kembang Tanjong). Pada kategori tambak yang sama, belum tentu masing-masing tambaknya memiliki jumlah koloni Vibrio sp. yang sama pula. Kisaran nilai kualitas air (suhu, salinitas, $\mathrm{pH}$, dan oksigen terlarut) pada semua tambak tergolong layak untuk budidaya udang windu, kecuali nilai kecerahan. Kualitas air tambak tidak memberi pengaruh signifikan terhadap kelimpahan bakteri Vibrio $s p$.

Diharapkan untuk dilakukan penelitian lanjutan mengenai identifikasi jenis-jenis bakteri Vibrio yang terdapat dalam air tambak sehingga dapat mengetahui cara penanggulangan apabila terjadi penyakit vibriosis dalam budidaya udang windu.

\section{DAFTAR PUSTAKA}

Apriliani, M., Sarjito, dan A. H. C., Haditomo. (2016). Keanekaragaman Agensia Penyebab Vibriosis pada Udang Vaname (Litopenaeus vanname) dan Sensitivitasnya terhadap Antibiotik. Journal of Aquaculture Management and Technology 5(1), 98-107.

Austin, B. (1988). Marine Microbiology. Cambridge University Press. England.

Badan Pusat Statistika. (2014). Pidie Dalam Angka; Pidie in Figure 2014. Badan Pusat Statistika Kabupaten Pidie, Aceh.

Bintari, N. W. D., Kawuri, R., dan A. A. G. R., Dalem (2016). Identifikasi Bakteri Vibrio Penyebab Vibriosis pada Larva Udang Galah (Macrobranchium (de Man)). Jurnal Biologi 20 (2), 53-63.

Campbell, Neil A., Reece Jane B., Mitchell, L., and Chain. (2011). Biologi Jilid 3. Erlangga. Jakarta.

Cappucino, J. G. and N., Sherman. (2011). Microbiology a Laboratory Manual Ed.9. Benjamin Cummings. San Francisco.

Chatterjee, S., and S. Haldar. (2012). Vibrio Related Diseases in Aquaculture and Development of Rapid and Accurate Identification Methods. J. Marine Sci Res Dev. 1-7.

Chau. N.T.T., Hieu, N.X., Thuan, L.T.N., Matsumoto, M., and I., Miyajima. (2011). Identification and Characterization of Actinomyces Antagonistic to Phatogenic 
Vibrio Spp. Isolated from Shrimp Culture Pond Sediments in Thua Thien HueViet Nam. J. Fac. Agr. Kyushu Univ 56 (1), 15-22.

Felix, F., Nugroho, T. T., Silalahi, S., dan Y., Octavia. (2011). Skrining Bakteri Vibrio Sp. Asli Indonesia Sebagai Penyebab Penyakit Udang Berbasis Tehnik 16s ribosomal DNA. Jurnal Ilmu dan Teknologi Kelautan Tropis 3 (2), 85-99.

Holt, J.G, Krieg, N.R., Sneath, P.H.A., Staley, J.T., and S.T., Williams. (1994). Bergey's Manual of Determinative Bacteriology. Ninth Edition. Williams \& Wilkins. Baltimore.

Ihsan, B., dan E. Retnaningrum. (2017). Isolasi dan Identifikasi Bakteri Vibrio sp. pada kerang Kapah (Meretrix meretrix) di Kabupaten Trenggalek. Jurnal Harpodon Borneo 10 (1), 23-27.

Irianto, A. (2005). Patologi Ikan Teleostei. Gadjah Mada University Press. Yogyakarta. Kharisma, A. dan A. Manan. (2012). Kelimpahan Bakteri Vibrio sp. pada air pembesaran udang vannamei (Litopenaeus vannamei) sebagai deteksi dini serangan penyakit vibriosis. J. Ilmiah Perikanan \& Kelautan 4 (2), 129-134.

Kordi, K.M.G.H. (2010). Budidaya Udang Laut. Lily Publisher. Yogyakarta.

Lay, B. W. (1994). Analisis Mikroba di Laboratorium. Raja Grafindo Persada. Jakarta. Lightner, D.V. (1996). A Handbook of Shrimp Pathology and Diagnostic Procedures for Diseases of Culture Penaeid Shrimp. Sec. 4: Bacteria, Vibriosis-culture and Identification. The World Aquaculture Society. Baton Rouge, Lousiana.

Mancuso, M., Genovese, L., and G., Maricchiolo. (2015). Brown Spot Disease in Penaeus kerathurus Eggs and Larvae: A Case Report. Int. J. of Curr. Microbiology and Appl. Sci. 4 (10), 938-944.

Radji, M. (2011). Buku Ajar Mikrobiologi Panduan Mahasiswa Farmasi dan Kedokteran. Buku Kedokteran EGC. Jakarta.

Rahmanto S.P., Sarjito, D., dan Chilmawati. (2014). Karakterisasi dan Uji Postulat Koch Bakteri Genus Vibrio yang Berasal dari Media Kultur Massal Mikroalga. Journal of Aquaculture Management and Technology 3 (4), 230-237.

Raissy, M., Momtaz, H., Moumeni, M., Ansari, M., and E. Rahimi. (2011). Molecular Detection of Vibrio spp. in Lobster Hemolymph. African Journal of Microbiology Reasearch 5 (13), 1697-1700. 
Ramesh, K., Natarajan, M., Sridhar, H., and S. Umamaheswari. (2014). Virulence Determination Among Vibrio harveyii Hatchery Isolated Through Haemolysis and Growth Constraint. Global Journal of Bio-Science and Biotechnology 3 (1), 109-114.

Sureshvarr, K., M. Jayakumar., and M. Prakash. (2011). Pretentious investigation of bacterial flora associated with fresh water prawn (Macrobrachium rosenbergii). Int. J. of Environ. Sci and Ecotechnology 1 (1), 45-53.

Tim Perikanan WWF-Indonesia. (2014). Better Management Practices: BMP Budidaya Udang Windu (Penaeus monodon) Tambak Tradisional dan Semi Intensif. WWF-Indonesia. Jakarta.

Tran, L., Nunan, L., Redman, R.M., Mohney, L.L., Pantoja, C.R., Fitzsimmons, K., and D. V. Lightner. (2013). Determination of the Infectious Nature of the Agent of Acute Hepatopancreatic Necrosis Syndrome Affecting Peneid Shrimp. Diseases of Aquatic Organisms 105, 45-55.

Tyas, D.E., Widyorini, N., dan Solichin, A. (2018). Perbedaan jumlah bakteri dalam sedimen pada kawasan bermanggrove dan tidak bermangrove di Perairan Desa Bedono, Demak. Journal of Maquares 7 (2), 189-196.

Zafran dan Rosa. (1998). Pengendalian Vibrio harveyi Secara Biologis pada Larva Udang Windu (Penaeus monodon). Jurnal Penelitian Perikanan Indonesia 4 (1), 24-29. 